\title{
UPAYA MENINGKATKAN KOMPETENSI GURU DALAM MENYUSUN RENCANA PELAKSANAAN PEMBELAJARAN (RPP) K13 MELALUI WORKSHOP DI SD NEGERI 57/II TALANG SILUNGKO 2
}

\author{
Warsiti \\ SDN 57/II Talang Silungko 2 \\ Email: warsitibungo1971@gmail.com
}

\begin{abstract}
Elementary School (SD) is the first basic education institution that plays an important role in the world of education in order to provide the basis for the next level of education. Elementary School is one of the nine-year compulsory basic education programs established by the government. Therefore, adequate management and handling of basic education in order to improve the quality of education is needed. This research aims to make teachers able to plan the implementation of learning, so that the material delivered by the teacher is more absorbed by students. Based on the results of interviews, the average teacher at Public Elementary School Number 57 / II TalangSilungko 2 has not been able to properly compile the learning tools, especially the Learning Implementation Plan (RPP) to overcome this problem, the author conducted research on Public Elementary School teachers Number 57 / II. TalangSilungko 2 is entitled: Efforts to Improve Teacher Competence in Preparing Learning Implementation Plans (RPP) through a Workshop at Public Elementary School Number 57 / II TalangSilungko 2 of 2019. Action research is carried out in 2 cycles and each cycle consists of 4 stages, namely planning, acting, observing and reflecting. It can be concluded that based on the results of action research through workshops followed by guidance from cycle to cycle there has been an increase in teacher competence, namely in the first cycle with an average of 60.4 , in the second cycle it became 76 .
\end{abstract}

Keywords: Teacher Competence, Learning Implementation Plan, Workshop

\begin{abstract}
Abstrak
Sekolah Dasar (SD) merupakan lembaga pendidikan dasar pertama yang memegang peranan penting dalam dunia pendidikan guna memberikan dasar terhadap tingkat pendidikan selanjutnya. Sekolah Dasar merupakan salah satu program pendidikan dasar wajib belajar sembilan tahun yang ditetapkan oleh pemerintah. Oleh karena itu, pengelolaan dan penanganan pendidikan dasar yang memadai demi meningkatkan mutu pendidikan sangat diperlukan. Penelitian ini bertujuan agar guru mampu merencanakan pelaksanaan pembelajaran, agar materi disampaikan guru lebih diserap oleh siswa.
\end{abstract}

Nur El-Islam, Volume 7, Nomor 2, Oktober 2020 
Upaya Meningkatkan Kompetensi ...

Berdasarkan hasil wawancara, rata rata guru di Sekolah Dasar Negeri Nomor 57/II Talang Silungko 2 belum mampu untuk menyusun Perangkat pembelajaran khususnya Rencana Pelaksanaan Pembelajaran (RPP) dengan baik untuk mengatasi masalah tersebut maka Penulis melakukan penelitian pada guru Sekolah Dasar Negeri Nomor 57/II Talang Silungko 2 tersebut dengan judul: Upaya Meningkatkan Kompetensi Guru dalam Menyusun Rencana Pelaksanaan Pembelajaran (RPP) Melalui Workshop di Sekolah Dasar Negeri Nomor 57/II Talang Silungko 2 tahun 2019. Penelitian tindakan dilaksanakan dalam 2 siklus dan masing masing siklus terdiri dari 4 tahab yaitu perencanan, pelaksanaan tindakan, observasi dan refleksi. Dapat disimpulkan bahwa berdasar hasil Penelitian tindakan melalui workshop dilanjutkan dengan pembimbingan dari siklus ke siklus telah terjadi peningkatan kompetensi guru, yaitu pada siklus pertama dengan rata-rata 60.4, pada siklus kedua menjadi 76 .

Kata Kunci: Kompetensi Guru, Rencana Pelaksanaan Pembelajaran, Workshop

\section{A. PENDAHULUAN}

1. Latar Belakang Masalah

Guru adalah ujung tombak di dunia pendidikan yang mengantarkan warga dunia untuk siap menghadapi masa depan. Maka tidak heran jika Jepang selepas perang dunia kedua yang telah menghancur leburkan negaranya segera mencari guru untuk membangun negerinya.Peran penting guru ini, tidak bisa diabaikan begitu saja. Baik pemerintah, stakeholder maupu pribadi guru sendiri. Kesadaran akan tugas mulianya, maka guru harus selalu meningkatkan kompetensinya. Di dalam menjalankan tugasnya, guru harus menguasai pokok bidang pekerjaannya, sehingga guru tersebut menjadi guru yang profesional.

Kompetensi guru di berbagai daerah di Indonesia sebagian besar masih dibawah standar kecukupan minimal (KCM) seperti yang telah ditetapkan pemerintah. Hal ini terbukti dengan hasil Uji Kompetensi Guru (UKG) tahun 2015 yang masih rendah. Untuk Propinsi Jambi nilai rata-rata guru mencapai 48.69, sedang nilai kecukupan minimal yang ditetapkan pemerintah adalah 55.00. Ada beberapa guru yang mendapat nilai di atas 70.00, guru-guru inilah yang menyumbangkan rata-rata sehingga mencapai 48.69. jika dianalisa berarti rata-rata guru di propinsi Jambi sangat rendah jika dikurang dengan guru-guru yang mempunyai nilai rata-rata di atas 70.00. 
Sekolah Dasar Nomor 57/II Talang Silungko berada di Kecamatan Bathin II Pelayang Kabupaten Bungo. Sekolah ini mempunyai 4 orang guru kelas dengan rata-rata UKG sebesar 37,2. Dari hasil ini dapat dipastikan bahwa guru-guru ini masih banyak memerlukan bimbingan dari kepala sekolah terutama dalam fungsinya sebagai seorang pendidik. Untuk itu penulis sebagai kepala sekolah secara intensif mengamati bagaimana guru-guru tersebut mengajar. Didukung dengan hasil wawancara dan lembar observasi maka penulis memperoleh beberapa masalah yaitu: 1). Guru kurang menguasai materi pembelajaran, 2). Guru kurang menguasai penyusunan perangkat pembelajaran. 3). Guru kurang fokus dalam melaksanakan tugasnya karena faktor pribadi.

Berdasarkan analisis masalah diatas maka penulis memutuskan untuk melakukan tindakan sekolah dengan mengangkat masalah kedua yaitu guru kurang menguasai penyusunan perangkat pembelajaran. Hal ini dipilih karena masalah ini merupakan ranah kepimpinan kepala sekolah. Untuk itu penulis merencanakan dan melaksanakan tindakan melalui workshop.

\section{Identifikasi Masalah}

Berdasarkan latar belakang di atas, maka masalah yang muncul dapat diidentifikasi sebagai berikut: (a) Guru kurang menguasai materi pembelajaran, (b) Guru kurang menguasai penyusunan perangkat pembelajaran dan (c) Guru kurang fokus dalam melaksanakan tugasnya karena faktor pribadi.

\section{Teori / Kajian}

a. Workshop

Kata workshop berasal dari Bahasa Inggris yang apabila diterjemahkan ke dalam Bahasa Indonesia berarti bengkel. Definisi workshop adalah sebuah kegiatan atau acara yang dilakukan, dimana beberapa orang yang memiliki keahlian di bidang tertentu 
berkumpul untuk membahas masalah tertentu dan mengajari para peserta. $^{1}$

Workshop adalah kegiatan atau acara yang dilakukan oleh beberapa orang, yang mempunyai keahlian di suatu bidang tertentu. Yang tujuannya adalah untuk membahas suatu masalah dan mengajari beberapa peserta workshop tersebut. pendek kata workshop adalah gabungan antara teori dan juga praktek, dalam suatu kegiatan. ${ }^{2}$ Workshop adalah program pendidikan tunggal yang dirancang untuk mengajarkan dan memperkenalkan kepada peserta ketrampilan praktis, tehnik, atau ide-ide yang dapat digunakan dalam pekerjaan mereka juga kehidupan sehari-hari. Workshop yang baik pada umumnya berkapasitas kecil, biasanya terdiri dari 6-15 supaya lebih fokus. Workshop biasanya dibuat untuk orang yang mempunyai minat yang sama atau bidang yang sama. Dengan tujuan memperbaiki dan mengembangkan sikap, tingkah laku, ketrampilan dan pengetahuan yang sesuai dengan minat individu yang bersangkutan. ${ }^{3}$

Selain pengertian diatas, berikut adalah pengertia workshop menurut beberapa situs web. Workshop adalah kegiatan yang dimana dalam kegiatan tersebut terdapat orang-orang yang memiliki keahlian dalam bidang tertentu, berkumpul lalu memabahas permasalahan tertentu dan memberi pengajaran/pelatihan kepada para peserta. ${ }^{4}$ Dengan adanya workshop diharapkan dapat mengembangkan peserta sesuai dengan kompetensinya dan menggunakan keahliannya sesuai dengan perubahan zaman. Pengertian tersebut memberi petunjuk bahwa untuk meningkatkan kompetensi guru dalam menyusun RPP sangat cocok menggunakan kegiatan workshop. Dengan kata lain workshop adalah suatu kegiatan yang menghasilkan sebuah produk, dalam hal ini adalah sebuah RPP.

${ }^{1}$ https://pakdosen.co.id/workshop-adalah/\#ftoc-heading-1

${ }^{2}$ https://tutorialbahasainggris.co.id/pengertian-workshop-menurut-para-ahli/

${ }^{3}$ Alex S. Nitisemito,Manajemen Personalia, Edisi Revisi, (Jakarta: Ghalia Indonesia, 1982), hlm. 10.

${ }^{4}$ https://www.dosenpendidikan.co.id/workshop-adalah/ 


\section{b. Guru}

Undang-Undang Guru dan Dosen No.14 Tahun 2005 "Guru adalah pendidik profesional dengan tugas utama mendidik, mengajar, membimbing, mengarahkan, melatih, menilai, dan mengevaluasi peserta didik pada pendidikan anak usia dini jalur pendidikan formal, pendidikan dasar, dan pendidikan menengah". ${ }^{5}$ Selanjutnya UU No.20 Tahun 2003 pasal 39 ayat 2 tentang sistem pendidikan nasional menyatakan, "pendidik merupakan tenaga profesional yang bertugas merencanakan dan melaksanakan proses pembelajaran, menilai hasil pembelajaran, melakukan pembimbingan dan pelatihan, serta melakukan penelitian dan pengabdian kepada masyarakat, terutama bagi pendidik pada perguruan tinggi." ${ }^{6}$

PP No.19 Tahun 2005 tentang Standar Nasional Pendidikan menyatakan, "pendidik (guru) harus memiliki kualifikasi akademik dan kompetensi sebagai agen pembelajaran, sehat jasmani dan rohani, serta memiliki kemampuan untuk mewujudkan tujuan pendidikan nasional." Berdasarkan definisi di atas, dapat disimpulkan bahwa guru adalah tenaga pendidik yang profesional dengan tugas utama mendidik, mengajar, membimbing, mengarahkan, melatih, menilai dan mengevaluasi peserta didik, dan bertugas merencanakan dan melaksanakan proses pembelajaran.

\section{c. Kompetensi Guru}

Kompetensi dalambahasa Indonesia merupakan serapan dari bahasa Inggris, competence yang berarti kecakapan dan kemampuan. Kompetensi adalah kumpulan pengetahuan, perilaku, dan ketrampilan yang harus dimiliki guru untuk mencapai tujuan pembelajaran dan

${ }^{5}$ Republik Indonesia, Undang-Undang Republik Indonesia Nomor 14 Tahun 2005 Tentang Guru dan Dosen, Bab. I, Pasal 1, ayat 1

${ }^{6}$ Republik Indonesia, Undang-Undang Republik Indonesia Nomor 20 Tahun 2003 Tentang Sistem Pendidikan Nasional, Bab. XI, Pasal 39, ayat 2

${ }^{7}$ Republik Indonesia, Peraturan Pemerintah Republik Indonesia Nomor 19 Tahun 2005 Tentang Standar Nasional Pendidikan, Bab. IV, Bagian Kesatu, Pasal 28, Ayat 1 
pendidikan.Kompetensi diperoleh melalui pendidikan, pelatihan, dan belajar mandiri dengan memanfaatkan sumber belajar. ${ }^{8}$

Menurut PP Nomor 74 Tahun 2008 Tentang Guru, bahwa Kompetensi merupakan seperangkat pengetahuan, keterampilan, dan perilaku yang harus dimiliki, dihayati, dikuasai, dan diaktualisasikan oleh Guru dalam melaksanakan tugas keprofesionalan. 9 Depdiknasmenyebutkanbahwa kompetensi diartikan, "sebagai pengetahuan, keterampilan, dan nilai-nilai dasar yang direfleksikan dalam kebiasaan berpikir dan bertindak". ${ }^{10}$

Menurut Uzer Usman "Kompetensi guru adalah kemampuan seorang guru dalam melaksanakan kewajiban-kewajibannya secara bertanggung jawab dan layak". ${ }^{11}$ Kompetensi guru rnerupakan perpaduan antara kemampuan personal, keilmuan, teknologi, sosial, dan spiritual yang secara menyeluruh membentuk kompetensi standar profesi guru, yang mencakuppenguasaanmateri, pemahamanterhadappesertadidik, pembelajaran yang mendidik, pengembanganpribadidanprofesionalisme.

Berdasarkan pendapat di atas dapat disimpulkan kompetensi adalah sebagai suatu kecakapan untuk melakukan sesuatu pekerjaan berkat pengetahuan, keterampilan ataupun keahlian yang dimiliki untuk melaksanakan suatu pekerjaan.Dengan demikian, kompetensi yang dimiliki oleh setiap guru akan menunjukkan kualitas guru yang sebenarnya. Keprofesionalan seorang guru akan ditunjukan dalam kemampuannya atau penguasaan kompetensi dalam menjalankan tugasnya sebagai guru.Menurut PP Nomor 74 Tahun 2008 Pasal 3 ayat 2 disebutkan bahwa, ada empat kompetensi yang harus dikuasi oleh guru dalam melaksanakan tugasnya yaitu: (1) kompetensi pedagogis;

8

http://www.jejakpendidikan.com/2016/11/pengertian-kompetensi-

guru.html?m=1

${ }^{9}$ Republik Indonesia, Peraturan Pemerintah Republik Indonesia Nomor 74 Tahun 2008 Tentang Guru, Bab. II, Bagian Kesatu, Pasal 3, Ayat 1

${ }^{10}$ Republik Indonesia, Depdiknas, Kerangka Dasar Kurikulum 2004, Jakarta, 2004.

11 http://www.pendidikanekonomi.com/2013/03/pengertian-kompetensi-

guru.html?m=1 
(2) kompetensi kepribadian; (3) kompetensi sosial; dan (4) kompetensi professional. ${ }^{12}$

\section{d. Rencana Pelaksanaan Pembelajaran}

Tugas guru dalam merencanakan pembelajaran adalah menyusun silabus dan rencana pelaksanaan pembelajaran, ini bagian dari administrasi guru.Silabus merupakan penjabaran standar kompetensi, kompetensi dasar, dan indikator ke dalam materi pokok/pembelajaran, kegiatan pembelajaran, dan pencapaian kompetensi untuk penilaian. Silabus juga merupakan sebagian subsistem pembelajaran yang terdiri dari atau yang satu sama yang lain saling berhubungan dalam rangka mencapai tujuan. Hal penting yang berkaitan dengan pembelajaran adalah penjabaran tujuan yang disusun berdasarkan indikator yang ditetapkan. ${ }^{13}$

Dalam Permendiknas No. 41 Tahun 2007 disebutkan bahwa, Rencana Pelaksanaan Pembelajaran (RPP) adalah rencana yang menggambarkan prosedur dan pengorganisasian pembelajaran untuk mencapai satu kompetensi dasar yang ditetapkan dalam standar isi dan telah dijabarkan dalam silabus. Lingkup Rencana Pelaksanaan Pembelajaran paling luas mencakup 1 (satu) kompetensi dasar yang terdiri atas beberapa indikator untuk 1 (satu) kali pertemuan atau lebih. ${ }^{14}$ PP No. 19 Tahun 2005 pasal 20 menyatakan bahwa, RPP minimal memuat sekurang-kurangnya lima komponen yang meliputi: (1) tujuan pembelajaran, (2) materi ajar, (3) metode pengajaran, (4) sumber belajar, dan (5) penilaian hasil belajar. ${ }^{15}$

Hal-hal yang perlu diperhatikan dalam menyusun RPP yaitu sebagai berikut: (a) RPP disusun untuk setiap KD yang dapat dilaksanakan dalam satu kali pertemuan atau lebih, b) tujuan

${ }^{12}$ Republik Indonesia, Peraturan Pemerintah Republik Indonesia Nomor 74 Tahun 2008 Tentang Guru, Bab. II, Bagian Kesatu, Pasal 3, Ayat 2

${ }^{13}$ Hamzah B. Uno, Mengelola Kecerdasan Dalam Pembelajaran, (Jakarta: Bumi Aksara, 2009), hlm. 23.

${ }^{14}$ Republik Indonesia, Permendiknas No. 41 Tahun 2007

${ }^{15}$ Republik Indonesia, Peraturan Pemerintah Republik Indonesia Nomor 19 Tahun 2005, Pasal 20 
pembelajaran menggambarkan proses dan hasil belajar yang harus dicapai oleh peserta didik sesuai dengan kompetenrsi dasar, c) tujuan pembelajaran dapat mencakupi sejumlah indikator, atau satu tujuan pembelajaran untuk beberapa indikator, yang penting tujuan pembelajaran harus mengacu pada pencapaian indikator, d) kegiatan pembelajaran dibuat setiap pertemuan, bila dalam satu RPP terdapat 3 kali pertemuan, maka dalam RPP tersebut terdapat 3 langkah pembelajaran, e) satu indikator dapat dibuat untuk lebih dari satu kali pertemuan. ${ }^{16}$

\section{e. Kerangka berfikir}

Untuk dapat melaksanakan pembelajaran dengan baik perlu menyusun perencanaan pembelajaran dengan baik pula, yaitu menyusun silabus dan rencana pelaksanaan pembelajaran.Guru seharusnya memahami mengenai tugasnya dan mempunyai tanggungjawab dalam mencapai keberhasilan peserta didiknya, motivasi harus selalu tumbuh dan ditingkatkan agar dalam melaksanakan tugasnya dapat berhasil dengan baik. Kemauan dan kemampuan menyusun RPP dengan cara workshop ini diharapkan akandiperoleh RPP yang baik dan menjadi acuan dalam mengajarnya. Penelitian ini didesain agar guru dalam menyusun RPP dengan bimbingan kepala sekolah, sehingga dihasilkan sebuah RPP yang sesui dengan standar kelayakan sesuai prosedur.

\section{Tujuan Penulisan}

Penelitian Tindakan Sekolah ini bertujuan untuk: (a) Meningkatkan kemampuan guru dalam menyusun Rencana Persiapan Pembelajarandan (b) Meningkatkan hasil belajar siswa.

${ }^{16}$ Eni Kurniawati, Pengembangan Bahan Ajar Bahasa dan Sastra Indonesia, 2009, Tesis, Surakarta: Program Pascasarjana Universitas Sebelas Maret. 


\section{B. Metodologi}

\section{Metodologi Penelitian}

Adapun yang menjadi subyek dalam PTS ini adalah 5 guru di SDN 57/II Talang Silungko.Penelitian Tindakan Sekolah dilaksanakan di SDN 57/II Talang Silungko Kabupaten Bungo, dimana tempat peneliti melaksanakan tugas sebagai kepala sekolah.PTS ini dilaksanakan pada semester ganjil Tahun Pelajaran 2019/2020 selama kurang lebih satu setengah bulan mulai Juli sampai dengan September 2019.

Penelitian ini berbentuk Penelitian Tindakan Sekolah, yaitu sebuah penelitian yang merupakan kerjasama antara peneliti dan guru, dalam meningkatkan kemampuan guru agar menjadi lebih baik dalam menyusun Rencana Pelaksanaan Pembelajaran . Penelitian ini bertujuan untuk mendeskripsikan kesulitan-kesulitan yang dialami oleh guru dalam menyusun RPP. Selanjutnya peneliti memberikan alternatif atau usaha guna meningkatkan kemampuan guru dalam membuat rencana pelaksanaan pembelajaran.

Prosedur penelitian adalah suatu rangkaian tahap-tahap penelitian dari awal sampai akhir. Penelitian ini merupakan proses pengkajian sistem berdaur sebagaimana kerangka berpikir yang dikembangkan oleh Suharsimi Arikunto dkk. Prosedur ini mencakup tahap-tahap: (1) perencanaan, (2) pelaksanaan, (3) pengamatan, dan (4) refleksi. Keempat kegiatan tersebut saling terkait dan secara urut membentuk sebuah siklus. Penelitian Tindakan Sekolah merupakan penelitian yang bersiklus, artinya penelitian dilakukan secara berulang dan berkelanjutan sampai tujuan penelitian dapat tercapai. ${ }^{17}$

Alur PTS dapat dilihat pada Gambar berikut

${ }^{17}$ Suharsimi Arikunto, Prosedur Penelitian: Suatu Pendekatan Praktik, (Jakarta: Rineka Cipta, 2011), hlm. 50 


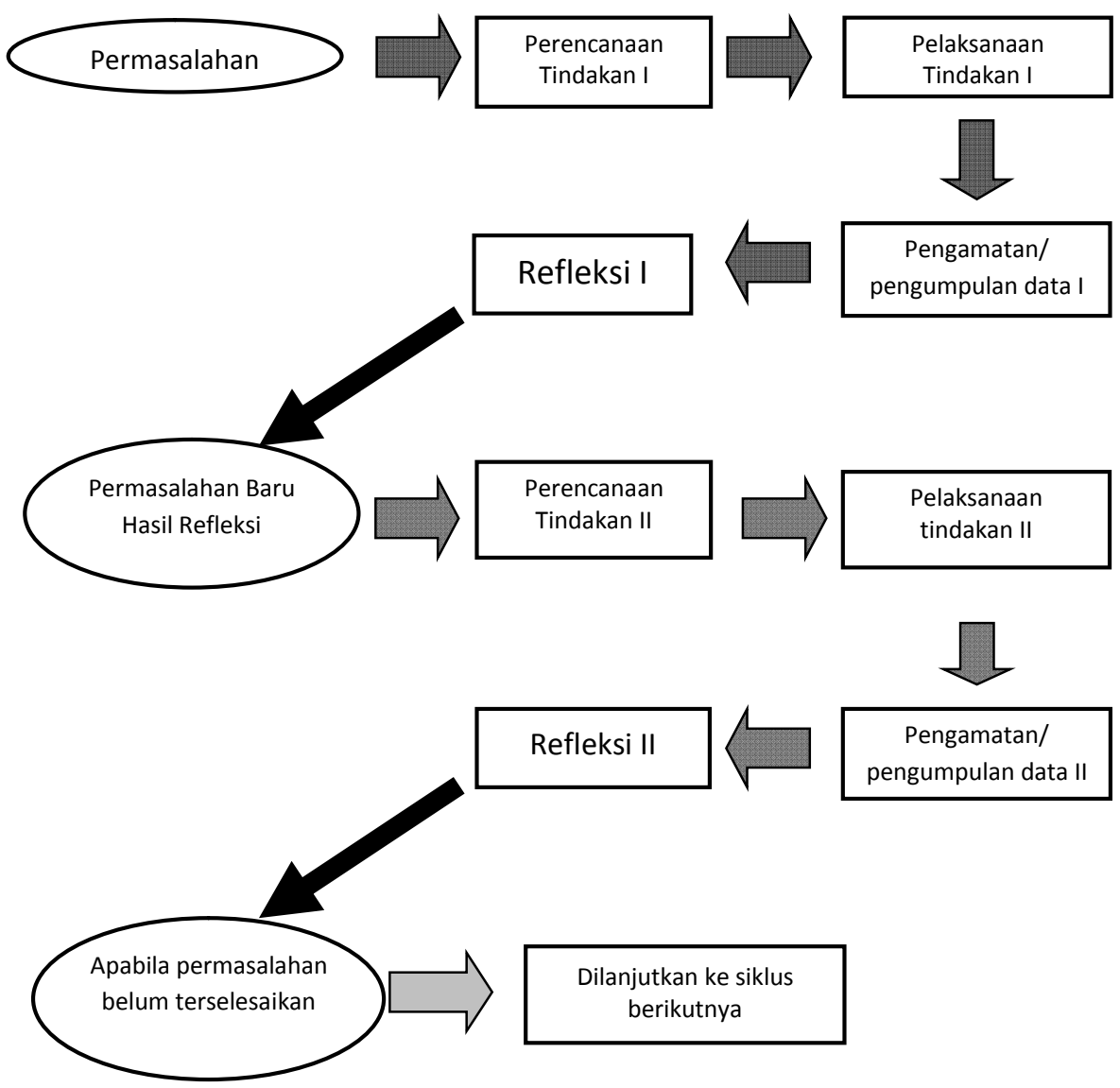

Gambar 1. Alur Penelitian Tindakan Sekolah

Teknik pengumpulan data dalam penelitian ini adalah wawancara, observasi, dan diskusi. Adapun rinciannya adalah sebagai berikut: 1) Wawancara dipergunakan untuk mendapatkan data atau informasi tentang pemahaman guru terhadap RPP. 2) Observasi dipergunakan untuk mengumpulkan data dan mengetahuikompetensi guru dalam menyusun Rencana Pelaksanaan Pembelajaran dengan lengkap.3) Diskusi dilakukan antara peneliti dengan guru.Alat pengumpulan data dalam PTS ini sebagai berikut: (a) Wawancara 
menggunakan panduan wawancara untuk mengetahui kemampuan awalyang dimiliki guru tentang Rencana Pelaksanaan Pembelajaran.(b) Observasi menggunakan lembar observasi atau angket untuk mengetahui komponen RPP yang telah dibuat dan yang belum dibuat oleh guru. (c) Diskusi dilakukan dengan maksud untuk saling berbagi pendapat antara peneliti dengan guru.

Rencana pelaksanaan dilakukan dalam dua siklus yaitu:

a. Siklus Pertama (Siklus I)

1) Peneliti merencanakan tindakan pada siklus I (membuat format/instrumen wawancara, penilaian RPP, rekapitulasi hasil penyusunan RPP).

2) Peneliti memberi kesempatan kepada guru untukmengemukakan kesulitan atau hambatan dalam menyusun Rencana Pelaksanaan Pembelajaran.

3) Peneliti menjelaskan kepada guru tentang pentingnya RPP dibuat secara lengkap dan baik.

4) Peneliti memberikan waktu untuk berdiskusi dalam menyusun RPP.

5) Peneliti melakukan observasi/pengamatan terhadap proses penyusunan RPP dengan bimbingan.

6) Peneliti dan guru melakukan refleksi.

b. Siklus Kedua (Siklus II)

1) Peneiti merencanakan tindakan pada siklus II yang mendasarkan pada hasilpenyusunan RPP dan pada refleksi siklus I.

2) Peneliti melaksanakan tindakan sesuai dengan rencana pada siklus II.

3) Peneliti melakukan observasi/pengamatan terhadap penyusunan RPPdengan cara guru berdiskusi.

4) Peneliti dan guru melakukan refleksi.

2. HipotesisPenelitian

Berdasarkan uraian diatas maka hipotesis penelitian adalah: "Kegiatan Workshop dapat Meningkatkan Kemampuan Guru dalam Menyusun RPP Kurkulum K13 di SDN 57/II Talang Silungko 2 Tahun 2019" 


\section{Pembahasan}

1. Temuan Penelitian

a. $\quad$ Profil SD No. 57 / II Talang Silungko 2

Penelitian ini dilaksanakan di SD No. 57 / II Talang Silungko 2 yang terletak di Kecamatan Bathin II Pelayang. Gedung sekolah berdiri diatas tanah seluas $50 \times 100 \mathrm{~m}$. gedung terdiri atas 5 ruang untuk kelas, 1 ruang kantor, dan 1 toilet umum.lingkungan SD NO. 57/ II Talang Silungko sangat sejuk karena letaknya di pedesaan dan kondisi sekolahnya pun bersih karena Guru selalu mengajak para siswa untuk sadar akan kesehatan.

Jumlah keseluruhan siswa SD No. 57/ II Talang Silungko 2 sebanyak 30 siswa diantaranya kelas 1 sebanyak 7 siswa, kelas 2 sebanyak 3 siswa, kelas 3 sebanyak 9 siswa, kelas 4 sebanyak 5 siswa, kelas 5 sebanyak 4 siswa dan kelas 6 sebanyak 4 siswa. Ditinjau dari kualitas pendidik sekolah ini masih standar minimal karena dari 5 orang guru baru 2 yang sudah sarjana dan 3 lainnya lulusan SPG

b. Perencanaan Tindakan

1) Identifikasi Masalah

Berdasarkan pembatasan masalah, yang diteliti adalah melalui supervise dapat meningkatkan kemampuan guru dalam menyusun RPP

2) Perencanaan Solusi Masalah

Tindakan dikembangkan berdasarkan penyebab masalah yaitu guru kurang mampu menyusun RPP sehingga pemahaman siswa serta hasil belajar kurang optimal. Tindakan yang akan dilaksanakan adalah melalui workshop dan pembimbingan.Tindakan pembimbingan ini dilaksanakan selama Bulan Juli-September 2019.

3) Pelaksanaan Tindakan

Penelitian ini merupakan penelitian tindakan sekolah maka dilaksanakan dalam dua siklus dengan pengambilan dua kalipenilaian. Penelitian ini dilaksanakan mulai bulan Juli-September2019.Tindakan dilaksanakan sesuai dengan rancangan pelaksanaan tindakan. 
4) Data Hasil Penelitian

\section{(a) Siklus I}

Upaya Meningkatkan Kemampuan Guru Dalam Menyusun Rencana Pelaksanaan Pembelajaran (RPP) kurikulum 13 melalui Workshop di SD Negeri 57/ II Talang Silungko 2 Tahun 2019.Menurut Undang-Undang Nomor 2 tahun 1989 tentang Sistem Pendidikan Nasional menyatakan,"komponen-komponen sistem pendidikan yang bersifat sumber daya manusia dapat digolongkan menjadi tenaga pendidik dan pengelola satuan pendidikan (penilik, pengawas, peneliti, dan pengembang pendidikan). “Tenaga gurulah yang mendapatkan perhatian lebih banyak di antara komponen-komponen sistem pendidikan. Usaha-usaha untuk mempersiapkan guru menjadi profesional telah banyak dilakukan. Kenyataan menunjukkan bahwa tidak semua guru memiliki kinerja yang baik dalam melaksanakan tugasnya. ${ }^{18}$

Peraturan Pemerintah Nomor 19 Tahun 2005 tentang 8 Standar Nasional Pendidikan menyatakan standar proses merupakan salah satu SNP untuk satuan pendidikan dasar dan menengah yang mencakup:1) Perencanaan proses pembelajaran, 2) Pelaksanaan proses pembelajaran, 3) Penilaian hasil pembelajaran, dan 4) Pengawasan proses pembelajaran. Perencanaan pembelajaran meliputi silabus dan Rencana Pelaksanaan Pembelajaran (RPP) yang dikembangkan oleh guru pada satuan pendidikan. Guru pada satuan pendidikan berkewajiban menyusun Silabus dan RPP secara lengkap dan sistematis agar pembelajaran berlangsung secara interaktif, Inspiratif, menyenangkan, menantang, memotivasi peserta didik untuk berpartisipasi aktif, serta memberikan ruang yang cukup bagi prakarsa, kreativitas, dan kemandirian sesuai dengan bakat, minat dan perkembangan fisik serta psikologis peserta didik. ${ }^{19}$

Masalah yang terjadi di lapangan,masih ditemukan adanya guru yang tidak bisa memperlihatkan RPP yang dibuat dengan alasan

\footnotetext{
${ }^{18}$ Republik Indonesia, Undang-Undang Republik Nomor 2 tahun 1989 tentang Sistem Pendidikan Nasional

${ }^{19}$ Republik Indonesia, Peraturan Pemerintah Republik Indonesia Nomor 19 Tahun 2005 tentang 8 Standar Nasional Pendidikan
} 
ketinggalan di rumah, dan bagi guru yang sudah membuat RPP masih ditemukan belum melengkapi komponen tujuan pembelajaran dan penilaian (soal, skor, dan kunci jawaban), serta langkah-langkah kegiatan pembelajarannya masih dangkal. Soal, skor, dan kunci jawaban merupakan satu kesatuan yang tidak dapat dipisahkan.

Permendikbud Nomor 81A Tahun 2013 (Lampiran 4) dijelaskan bahwa Rencana Pelaksanaan Pembelajaran (RPP) adalah rencana pembelajaran yang dikembangkan secara rinci dari suatu materi pokok atau tema tertentu yang mengacu pada silabus. RPP harus dibuat agar kegiatan pembelajaran berjalan sistematis dan mencapai tujuan pembelajaran. Tanpa RPP biasanya pembelajaran tidak terarah. Oleh karena itu, guru harus mampu menyusun RPP dengan lengkap berdasarkan silabus yang ada (disusunya). RPP sangat penting bagi seorang guru karena merupakan acuan dalam melaksanakan proses pembelajaran. ${ }^{20}$ Permasalahan guru di SDN 57/ II Talang Silungko 2 adalah 1) Guru belum paham dalam menyusun RPP kurikulum 2013, 2) RPP kurikulum 13 yang dibuat guru belum lengkap. Dari 3 orang guru yang menggunakan kurikulum 2013, belum ada yang mampu menyusun RPP kurikulum 13 dengan lengkap.

\section{(1) Persiapan Tindakan Siklus Pertama}

Rancangan tindakan siklus I, di awali dengan berdiskusi dengan pengawas sekolah mengenai pentingnya RPP oleh semua guru sebagai pedoman dalam kegiatan proses belajar mengajar. Salah satunya Meningkatkan Kemampuan Guru dalam menyusun RPP kurikulum 2013 melalui workshop. Hasil diskusi dengan pengawas sekolah tersebut disosialisalisasikan kepada guru-guru kemudian diputuskan untuk menyelenggarakan kegiatan penyusunan RPP kurikulum 2013 pada hari Selasa tanggal 17 Juli 2019 yang di mulai pukul 08.00. Adapun kegiatan-kegiatan yang dilakukan dalam tahap perencanaan adalah sebagai berikut

a. Menyusun program kerja sebagai acuan dalam melaksanakan kegiatan workshop.

${ }^{20}$ Republik Indonesia, PermendikbudNomor 81A Tahun 2013 (Lampiran 4) 
b. Menyusun materi dalam power point untuk menyampaikan materi agar lebih mudah dipahami oleh guru-guru mengenai prosedur penyusunan Rencana Pelaksanaan Pembelajaran (RPP).

c. Untuk mengefektifkan pelaksanaan workshop, penulis menyusun jadwal kegiatan.

(2) Pelaksanaan Tindakan Siklus Pertama

Pelaksanaan proses pengembangan Rencana Pelaksanaan

Pembelajaran (RPP) kurikulum 2013. Peserta dalam kegiatan ini adalah guru-guru SDN 57/ II Talang Silungko 2yang mengajar dengan menggunakan kurikulum 2013 sebanyak 4 orang. Disini kepala sekolah memberikan penjelasan tentang:

i. Merumuskan tujuan pembelajaran.

ii. Memilih materi ajar sesuai dengan tujuan dan karakteristik peserta didik.

iii. Mengalokasi waktu sesuai dengan materi ajar.

iv. Menentukan materi.

v. Menentukan metode pembelajaran.

vi. Memilih sumber/media pembelajaran yang sesuai dengan tujuan dan materi ajar.

vii. Membuat skenario pembelajaran secara sistematis.

viii. Menyusun instrumen penilaian dengan lengkap dan benar.

Kegiatanyang dilakukan oleh kepalas ekolah memfasilitasi peserta berupa bahan/materi yang akan disampaikan. kepala sekolah menjelaskan defenisi RPP prinsip-prinsip pengembangan RPP kurikulum2013, komponen-komponen RPP kurikulum2013, manfaat RPP dan penerapan pelaksanan pembelajaran dalam sebuah RPP kepada peserta/guru. Selain memberikan penjelasan kepala sekolah dan narasumber malakukan tanya jawab dengan peserta tantang RPP kurikulum 2013 tersebut. Setelah penjelasan diperkirakan cukup, maka peserta/guru diberi tugas untuk mengkaji RPP model yang diberikan oleh kepala sekolah kepada peserta/guru dengan menggunakan instrumen yang telah disiapkan oleh kepala sekolah. Dari hasil kajian RPP tersebut selanjutnya dianalisis bersama-sama oleh kepala sekolah, dan guru. Kemudian berikutnya peserta/guru 
diberi tugas untuk merancangsendiri RPP kurikulum 2013 dengan KompetensiInti, kopetensidasar, dan silabus yang telah ditentukan kepala sekolah, untuk mengetahui kepastian penyerapan atau penguasaan peserta/guru dalam mengambangkan RPP.

a. Monev

Kegiatan monev dilakukan dengan langkah - langkah sebagai berikut:

1) Guru/peserta dan kepala sekolah melakukan pemantauan selama kegiatan berlangsung.

2) Mengamati bagaimana respon/motivasi guru-guru dalam mengikuti kegiatan.

3) Semua pendidik dan tenaga kependidikan dilibatkan oleh kepala sekolah dalam kegiatan

4) Sebagian guru antusias mengikuti kegiatan.

5) Setelah selesai kegiatan dilakukan kepala sekolah melakukan evaluasi untuk menentukan perlu tidaknya rencana tindak lanjut.

Hasil dari kegiatan monev siklus 1 ini dapat dilihat dari tabel berikut:

Tabel1. RekapitulasiPeningkatanKompetensi Guru Siklus 1

\begin{tabular}{|c|c|c|c|c|c|c|c|}
\hline \multirow[t]{2}{*}{ No } & \multirow[t]{2}{*}{ Uraiankegiatan } & \multicolumn{4}{|c|}{ Skor } & \multirow[t]{2}{*}{$\begin{array}{c}\text { Jml } \\
\text { Responden }\end{array}$} & \multirow[t]{2}{*}{$\begin{array}{l}\text { Jml } \\
\text { Skor }\end{array}$} \\
\hline & & 1 & 2 & 3 & 4 & & \\
\hline 1 & $\begin{array}{l}\text { Menentukan materi } \\
\text { RPP }\end{array}$ & & 2 & 2 & & 4 & 10 \\
\hline 2 & $\begin{array}{l}\text { Merumuskan } \\
\text { penggunaan bahasa } \\
\text { yang tepatpada RPP } \\
\text { sesuai dengan } \\
\text { regulasi yang telah } \\
\text { ditetapkan }\end{array}$ & & 2 & 2 & & 4 & 10 \\
\hline 3 & $\begin{array}{l}\text { Memilih dan } \\
\text { menyusun materi ajar } \\
\text { yang sesuai dengan } \\
\text { RPP kurikulum } 13\end{array}$ & & 2 & 1 & 1 & 4 & 11 \\
\hline
\end{tabular}




\begin{tabular}{|l|l|l|l|l|l|l|c|}
\hline 4 & $\begin{array}{l}\text { Memilih dan } \\
\text { menentukan metode } \\
\text { pembelajaran pada } \\
\text { RPP kurikulum 13 }\end{array}$ & 3 & 1 & & 4 & 9 \\
\hline 5 & $\begin{array}{l}\text { Memilih } \\
\text { sumber/media } \\
\text { pembelajaran yang } \\
\text { sesuai dengan tujuan } \\
\text { dan materi ajar }\end{array}$ & 1 & 2 & 1 & 4 & 2 \\
\hline 6 & $\begin{array}{l}\text { Menyusun instrument } \\
\text { penilaian dengan } \\
\text { lengkap dan benar }\end{array}$ & 1 & 2 & 1 & & 4 & 8 \\
\hline Jumlahskor & 1 & 12 & 9 & 2 & & 58 \\
\hline Jumlahnilai & 1 & 22 & 27 & 8 & & \\
\hline
\end{tabular}

Catatan :

Skor 1 : tidak lengkap

Skor 2 : cukup lengkap

Skor 3 : sebagian besar lengkap

Skor 4 : lengkap

$\begin{array}{ll}\text { Amatbaik } & 86-100 \\ \text { Baik } & 71-85 \\ \text { Cukup } & 55-70 \\ \text { Kurang } & 00-54\end{array}$

Rata-rata peningkatan kompetensi guru $=58 \times 100 / 96=60,4$ dengan Kualifikasi Cukup

b. Refleksi Tindakan Siklus Pertama

Kegiatan workshop siklus pertama, guru-guru sangat antusias mengikuti kegiatan. Dalam kegiatan ini sebagian besar guru-guru merasa tidak mampu menyusun RPP. Penulis selaku penyelenggara berusaha menyemangati dengan selalu menanyakan sudah sampai bagian yang mana dan mengingatkan acara workshop bagi guru-guru sesuai dengan kesepakatan awal.Kegiatan penyusunan RPP kurikulum 2013 ini hambatan dan kesulitan terutama masih adanya peserta yang kesulitan menerima penjelasan tentang komponen-komponen, langkah-langah dalam menyusun RPP kurikulum 2013. keberhasilan yang telah dicapai dalam kegiatan ini adalah perolehan hasil dari rekapitulasi untuk keterlaksanaan program diperoleh nilai 83 dengan kualifikasi baik, sedangkan pada peningkatan kompetensi guru 
diperoleh nilai 60 dengan kualifikasi cukup. Sedangkan hasil monitoring dan evaluasi yang dilakukan kepala sekolah terhadap guru-guru dalam menyusun RPP kurikulum 2013 adalah sebagai berikut:

Tabel 2Hasil monev penyusunan RPP Siklus 1

\begin{tabular}{|c|c|c|c|c|c|c|c|c|c|c|}
\hline \multirow{2}{*}{$\begin{array}{l}\mathrm{N} \\
\mathrm{o}\end{array}$} & \multirow[t]{2}{*}{ Nama Guru } & \multicolumn{6}{|c|}{ Nomor Instruman } & \multirow[t]{2}{*}{ Jml } & \multirow{2}{*}{$\begin{array}{l}\text { Skor } \\
\text { (\%) }\end{array}$} & \multirow[t]{2}{*}{ Ket } \\
\hline & & 1 & 2 & 3 & 4 & 5 & 6 & & & \\
\hline 1 & $\begin{array}{l}\text { Elifnawati, } \\
\text { S.Pd }\end{array}$ & 3 & 2 & 2 & 2 & 2 & 2 & 13 & 54 & kurang \\
\hline 2 & Aisyah,S.Pd & 3 & 3 & 3 & 4 & 3 & 3 & 19 & 79 & Baik \\
\hline 3 & Nuraini & 2 & 2 & 2 & 2 & 2 & 1 & 11 & 45,8 & kurang \\
\hline 4 & Darmilah & 3 & 2 & 3 & 2 & 3 & 2 & 15 & 62,5 & Cukup \\
\hline
\end{tabular}

Kriteria nilai yang digunakan

\begin{tabular}{|l|l|l|}
\hline Angka & Huruf & Keterangan \\
\hline $86-100$ & A & Sangat Baik \\
\hline $71-85$ & B & Baik \\
\hline $56-70$ & C & Cukup \\
\hline$<55$ & D & Kurang \\
\hline
\end{tabular}

Dari 4 orang guru yang sebagai peserta dalam penyusunan Rencana Pelaksanaan Pembelajaran (RPP) kurikulum 2013 ini, ada 1 orang yang berkualifikasi baik dan 1 orang yang berkualifikasi cukup, dan 2 orang dengan kualifikasi kurang. Dari ke 3 orang guru yang berkualifikasi cukup dan kurang inilah nanti di siklus kedua akan dilakukan bimbingan yang lebih intensif lagi, agar lebih mengerti dan memahami dalam menyusun Rencana Pelaksanaan Pembelajaran (RPP) kurikulum 2013 ini. 


\section{(b) Siklus Kedua}

(1) Persiapan Siklus Kedua

Berdasarkan hasil pelaksanaan workshop pada siklus I terutama pada penyusunan langkah-langkah kegiatan dalam RPP yang masih kurang. Adapun kegiatan yang dilakukan menyusun program workshop dalam penyempurnaan RPP, meminta guru-guru yang sudah memiliki kemampuan amat baik dalam menyusun langkahlangkah kegiatan dalam RPP untuk turut memberikan bimbingan pada guru-guru.

(2) Pelaksanaan Siklus Kedua

Pelaksanaan proses pengembangan rencana pelaksanaan pembelajaran yang kedua, kepala sekolah disini tetap sebagai narasumber untuk penyampaian materi, hanya yang lebih kreatif adalah pesertanya dan peserta yang telah memahami penyusunan RPP membantu peserta lainnya yang belum paham. Kepala sekolah memberikan pembelajaran ulang tentang defenisi RPP prinsip-prinsip pengembangan RPP, komponen-komponen RPP, manfaat RPP, cara memadukan nilai karakter bangsa dan penerapan pelaksanan pembelajaran terkait dengan hasil pelaksanaan pertama yang hasilnya masih perlu perbaikan dan peningkatan. Dalam kegiatan ini peserta/guru lebih ditentukan pada ketelitian dalam mengkaji RPP yang dijadikan bahan kajian sehingga guru-guru dapat menemukan kesenjanganya. Dari hasil kajian RPP tersebut selanjutnya dianalisis bersama-sama oleh kepala sekolah dan guru, kemudian berikutnya peserta/guru diberi tugas untuk merancang/membuat sendiri RPP berbasis karakter dengan kopetensi dasar dan silabus yang telah ditentukan kepala sekolah, untuk mengetahui kepastian penyerapan atau penguasaan peserta/guru dalam pembuatan RPP kurikulum 2013.

(3) Monev Siklus Kedua

Monitoring dan evaluasi dilakukan guru/peserta dan kepala sekolah sesuai dengan instrumen yang telah disediakan kepala sekolah. Monev dilakukan berdasarkan:

1) Dilakukan melalui mekanisme tahapan persiapan, pelaksanaan, analisis dan tindak lanjut. 
Upaya Meningkatkan Kompetensi ...

2) Disampaikan dengan menggunakan materi dan instrument yang relevan.

3) Informasi diperoleh secara lisan atau berdasarkan bukti dan fakta

4) Hasil monev diinformasikan kepada guru untuk memperoleh umpan balik.

Hasil dari monev siklus ke-2 dapat dilihatkan berdasarkan tabel berikut

Tabel 3. Rekapitulasi Peningkatan Kompetensi Guru Siklus II

\begin{tabular}{|c|c|c|c|c|c|c|c|}
\hline \multirow{2}{*}{$\begin{array}{l}\mathrm{N} \\
\mathrm{o}\end{array}$} & \multirow{2}{*}{ Uraian kegiatan } & \multicolumn{4}{|c|}{ Skor } & \multirow{2}{*}{$\begin{array}{l}\text { Jml } \\
\text { Respo } \\
\text { nden }\end{array}$} & \multirow{2}{*}{$\begin{array}{l}\text { Jml } \\
\text { Sko } \\
\text { r }\end{array}$} \\
\hline & & 1 & 2 & 3 & 4 & & \\
\hline 1 & $\begin{array}{l}\text { Menyusun RPP dengan menggunakan } \\
\text { struktur penyusunan RPP kurikulum } \\
\text { 13, tepat, dan sesuai dengan yang } \\
\text { telah ditetapkan }\end{array}$ & & & 3 & 1 & 4 & 13 \\
\hline 2 & $\begin{array}{l}\text { Merumuskan penggunaan bahasa } \\
\text { yang tepat pada RPP sesuai dengan } \\
\text { regulasi yang telah ditetapkan }\end{array}$ & & 1 & 3 & & 4 & 11 \\
\hline 3 & $\begin{array}{l}\text { Memilih dan menyusun materi ajar } \\
\text { yang sesuai dengan RPP kurikulum } 13\end{array}$ & & & 4 & & 4 & 12 \\
\hline 4 & $\begin{array}{l}\text { Memilih dan menentukan metode } \\
\text { pembelajaran pada RPP kurikulum } 13\end{array}$ & & & 3 & 1 & 4 & 13 \\
\hline 5 & $\begin{array}{l}\text { Memilih sumber/media pembelajaran } \\
\text { yang sesuai dengan tujuan dan materi } \\
\text { ajar }\end{array}$ & & & 3 & 1 & 4 & 13 \\
\hline 6 & $\begin{array}{l}\text { Menyusun instrumen penilaian } \\
\text { dengan lengkap dan benar }\end{array}$ & & 1 & 3 & & 4 & 10 \\
\hline \multicolumn{2}{|c|}{ Jumlahskor } & & 2 & 19 & 3 & & \\
\hline \multicolumn{2}{|c|}{ Jumlahnilai } & & 4 & 57 & 12 & & 73 \\
\hline
\end{tabular}


Catatan :

Skor 1 :

lengkap

Skor2

lengkap

Skor3

besar lengkap

Skor4 :lengkap

\begin{tabular}{|c|c|c|}
\hline & Amatbaik & $86-100$ \\
\hline \multirow{2}{*}{ :cukup } & Baik & $71-85$ \\
\hline & Cukup & $55-70$ \\
\hline ohagian & Kurang & $00-54$ \\
\hline
\end{tabular}

Rata - rata peningkatankompetensi $=73 \times 100 / 96$ Nilai 76 Kualifikasi B

b. Refleksi Siklus Kedua

Pelaksanaan workshop pada siklus kedua, dapat berjalan lebih efektif, Pada siklus II ini Kepala sekolah dapat memonitor pelaksanaan kegiatan workshop terutama terhadap 3 orang guru yang masih memiliki kekurangan dalam penyusunan RPP kurikulum 13 dan selalu memotivasi agar guru-guru mampu menyelesaikan tugas yang mendukung profesionalisme guru.

Tabel4.Hasil Monev Penyusunan RPP siklus II

\begin{tabular}{|l|l|c|c|c|c|c|c|l|l|l|}
\hline \multirow{2}{*}{$\begin{array}{l}\text { N } \\
\mathbf{0}\end{array}$} & Nama Guru & \multicolumn{4}{|l|}{ Nomor } & & Jml & $\begin{array}{l}\text { Skor } \\
(\%)\end{array}$ & Ket \\
\cline { 2 - 10 } & & 1 & 2 & 3 & 4 & 5 & 6 & & & \\
\hline 1 & $\begin{array}{l}\text { Elifnawati, } \\
\text { S.Pd }\end{array}$ & 3 & 3 & 3 & 3 & 3 & 2 & 17 & 70,8 & Cukup \\
\hline 2 & Aisyah,S.Pd & 4 & 3 & 3 & 4 & 3 & 3 & 20 & 83 & Baik \\
\hline 3 & Nuraini & 3 & 2 & 3 & 3 & 3 & 3 & 17 & 70,8 & Cukup \\
\hline 4 & Darmilah & 3 & 3 & 3 & 3 & 4 & 3 & 19 & 79 & Baik \\
\hline
\end{tabular}

Kriteria nilai yang digunakan

\begin{tabular}{|l|l|l|}
\hline ANGKA & HURUF & KETERANGAN \\
\hline $86-100$ & A & Sangat Baik \\
\hline $71-85$ & B & Baik \\
\hline
\end{tabular}


Upaya Meningkatkan Kompetensi ...

\begin{tabular}{|l|l|l|}
\hline $56-70$ & C & Cukup \\
\hline$<55$ & D & Kurang \\
\hline
\end{tabular}

\section{Pembahasan}

Dalam penelitian yang dilakukan di SDN SOKASARI 02 Kecamatan Bumijawa pada tahun ajaran 2017/2018 oleh Safrudin, dapat disimpulkan bahwa kendala akan rendahnya kompetensi guru dalam menyusun RPP di SDN SOKASARI 02 dengan kegiatan workshop penyusunan RPP mengalami peningkatan yang signifikan pada setiap siklusnya. ${ }^{21}$

Penelitian lain yang menggunakan metode Workshop untuk meningkatkan kompetensi guru dalam menyusun Rencana Pelaksanaan Pembelajaran juga dilakukan oleh Mamik Srimulyani Dinas Pendidikan Kota Malang . Dari kegiatan tersebut dapat disimpulkan bahwa peningkatan kompetensi guru dalam menyusun RPP/RPLBK dengan pendekatan saintifik dan pendekatan BK di SMP binaan khusunya di SMP Negeri 7 Kota Malang, SMP plus Az-zahroh, dan SMP Waskita Dharma dapat ditingkatkan melalui metode workshop ${ }^{22}$

Sebagaimana penelitian di atas. Penelitian ini meliputi siklus I dengan pelaksanaan kegiatan berupa workshop yang dilakukan dengan cara pemberian materi secara umum tentang cara penyusunan Rencana Pelaksanaan Pembelajaran, dilanjutkan dengan praktik menyusun Rencana Pelaksanaan Pembelajaran sesuai petunjuk pada materi workshop didampingi fasilitator. Kemudian praktik menyusun Rencana Pelaksanaan Pembelajaran secara mandiri. Hasilnya diamati

${ }^{21}$ Jurnal Dialektika Jurusan PGSD, Vol. 9 No. 2 September 2019, Safrudin, Penigkatan Kompetensi Guru Dalam Menyusun RPP Melalui Kegiatan Workshop Bagi Para Guru SDN SOKASARI 02 kecamatan Tegal Bumijawa Kabupaten Tegal, Semester II Tahum Pelajaran 2017/2018.

${ }^{22}$ http://research-report.umm.ac.id/index.php/SENASGABUD (Seminar Nasional Lembaga Kebudayaan) Edisi 1 Tahun 2017 ,Mamik Sri Mulyani,Meningkatkan Kompetensi Guru dalam Menyusun RPP/RPLBK dengan Pendekatan Saintifik/Pendekatan BK Melalui Metode Workshop di Sekolah Binaan Kota Malang, Tahun 2017 
dan diperiksa sesuai instrumen yang telah disediakan dalam siklus I ini. Pada siklus IIdilakukan pemdampingan terhadap peserta untuk memberikan masukan perbaikan berdasarkan hasil pada siklus I maka terdapat peningkatan dari rata-rata peningkatan kompetensi guru/peserta di siklus I yang memperoleh rata-rata 60,4 dengan kualifikasi cukup, pada siklus II dilakukan kegiatan pendampingan/pembimbingan sehingga hasilnya meningkat menjadi 76 dengan kualifikasi Baik. Tiga orang guru yang mendapat bimbingan yang lebih intensif di siklus II ini ketiga guru tersebut telah mengalami peningkatan yang signifikan. Peningkatan dari hasil monev dapat dilihat dari grafik berikut :

Grafik 1. Hasil Monev Siklus 1 dan Siklus 2

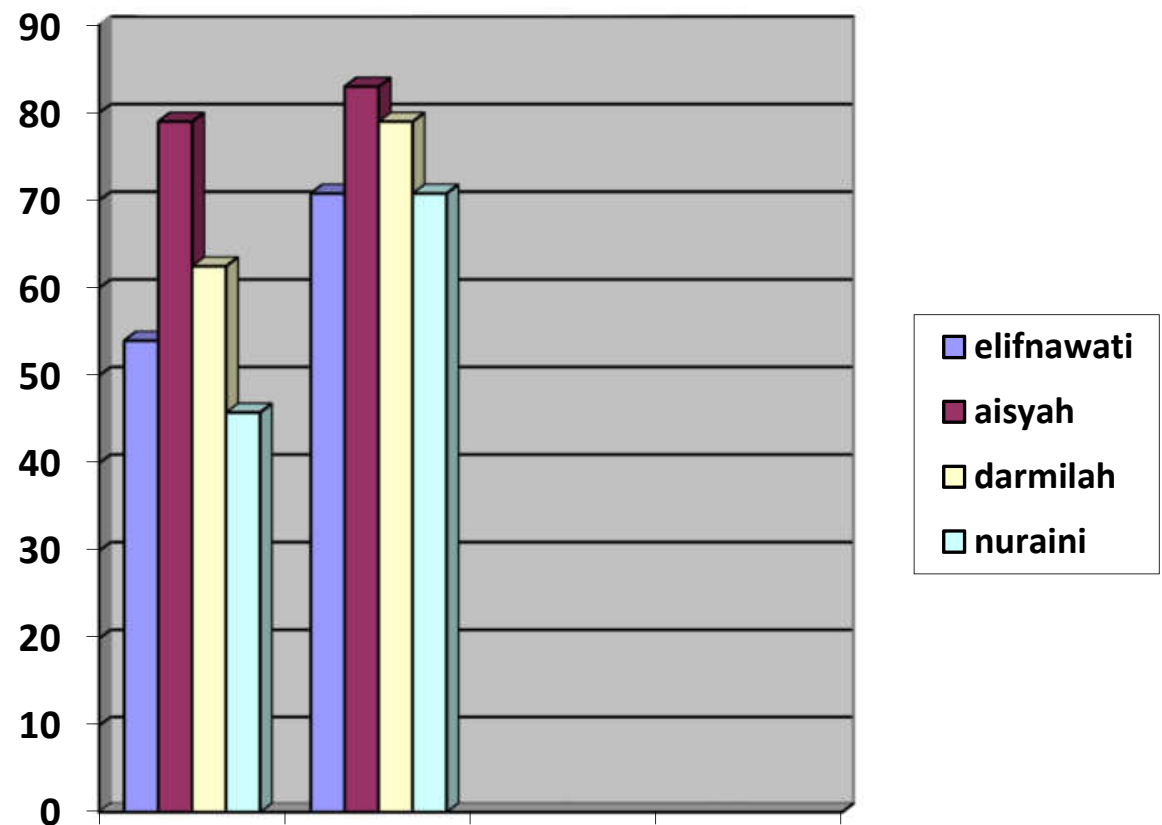

siklus 1 siklus 2 
Dari grafik di atas dapat dilihat Elifnawati pada siklus 1 yaitu pada saat pelaksanaan workshop, setelah pemberian materi cara penyusunan Rencana Pelaksanaan Pembelajaran, maka yang bersangkutan mengerjakan tugas merancang Rencana Pelaksanaan Pembelajaran sendiri, setelah di amati dengan mengunakan instrumen yang disediakan, maka memperoleh nilai kompetensi 54, dari hasil pengamatan kompetensi Elifnawati masih begitu rendah maka dilakukan tindakan pembimbingan/pendampingan dengan tujuan menemukan kesukitan yang dihadapi untuk kemudian dilakukan perbaikan perbaikan.

Selanjutnya Elifnawati kembali menyusun rancangan Rencana Pelaksanaan Pembelajaran kembali. Setelah diamati dengan menggunakan instrumen yang telah disiapkan maka perolehan nilai meningkat sehingga siklus kedua menjadi 70. Sementara Aisyah pada siklus 1 yaitu pada saat pelaksanaan workshop, setelah pemberian materi cara penyusunan Rencana Pelaksanaan Pembelajaran, maka yang bersangkutan mengerjakan tugas merancang Rencana Pelaksanaan Pembelajaran sendiri, setelah di amati dengan mengunakan instrumen yang disediakan, maka memperoleh nilai kompetensi 79, dari hasil pengamatan kompetensi Aisyah tertinggi dibandingkan peserta yang lainnya.

Namun demikian tetap dilakukan tindakan pembimbingan/pendampingan dengan tujuan menemukan kesulitan yang dihadapi untuk kemudian dilakukan perbaikan perbaikan. Selanjutnya Aisyah kembali menyusun rancangan Rencana Pelaksanaan Pembelajaran kembali. Setelah diamati dengan menggunakan instrumen yang telah disiapkan maka perolehan nilai meningkat sehingga siklus kedua meningkat menjadi 83, begitu juga dengan Darmilah yang pada siklus Iyaitu pada saat pelaksanaan workshop, setelah pemberian materi cara penyusunan Rencana Pelaksanaan Pembelajaran, maka yang bersangkutan mengerjakan tugas merancang Rencana Pelaksanaan Pembelajaran sendiri, setelah di amati dengan mengunakan instrumen yang disediakan, maka memperoleh nilai kompetensi 62, dari hasil pengamatan kompetensi Darmilah masih rendah maka dilakukan tindakan 
pembimbingan/pendampingan dengan tujuan menemukan kesulitan yang dihadapi untuk kemudian dilakukan perbaikan perbaikan.

Selanjutnya Darmilah kembali menyusun rancangan Rencana Pelaksanaan Pembelajaran kembali. Setelah diamati dengan menggunakan instrumen yang telah disiapkan maka perolehan nilai meningkat sehingga siklus kedua meningkat menjadi 79, dan sample terakhir yaitu Nuraini pada siklus Iyaitu pada saat pelaksanaan workshop, setelah pemberian materi cara penyusunan Rencana Pelaksanaan Pembelajaran, maka yang bersangkutan mengerjakan tugas merancang Rencana Pelaksanaan Pembelajaran sendiri, setelah di amati dengan mengunakan instrumen yang disediakan, maka memperoleh nilai kompetensi 45 dari hasil pengamatan kompetensi Nuraini masih begitu rendah maka dilakukan tindakan pembimbingan/pendampingan dengan tujuan menemukan kesulitan yang dihadapi untuk kemudian dilakukan perbaikan perbaikan. Selanjutnya Nuraini kembali menyusun rancangan Rencana Pelaksanaan Pembelajaran kembali. Setelah diamati dengan menggunakan instrumen yang telah disiapkan maka perolehan nilai meningkat sehingga siklus kedua mendapat kenaikan menjadi 70.

\section{Penutup}

1. Simpulan

Kemampuan penulis melakukan Penelitian Tindakan Sekolah tidak terlepas dari upaya penulis meningkatkan kinerja sebagai kepala sekolah yang profesional. Penulis melakukan Penelitian Tindakan Sekolah pada SD Negeri Nomor 57/II Talang Silungko 2, Kec. Bathin II Pelayang, Kab. Bungo. Dilakukannya Penelitian Tindakan Sekolah ini merupakan implementasi tugas penulis sebagai kepala sekolah.

Hasil observasi mengungkapkan kemajuan penulis dalam mengupayakan peningkatan kompetensi guru dalam menyusun Rencana Pelaksanaan Pembelajaran. Ini dibuktikan dengan peningkatan kompetensi guru dalam menyusun RPP dari siklus 1 ke siklus 2. Hal ini tidak terlepas dari kemampuan penulis mengoptimalkan pelaksanaan workshop khususnya mengenai penyusunan Rencana Pelaksanaan Pembelajaran, Hasil kegiatan ini 
harus ditindaklanjuti dengan penerapannya dalam pembelajaran di kelas, agar memberikan dampak yang nyata untuk meningkatkan pemahaman konsep dan hasil belajar siswa serta profesionalisme guru. Dampak nyata ini diharapkan dapat dirasakan masyarakat maupun stakeholders.

\section{Saran dan Tindak Lanjut}

Beberapa saran penulis sampaikan kepada sidang pembaca, khususnya para kepala sekolah yang hendak melakukan penelitian tindakan sekolah. Kendati Penelitian Tindakan Sekolah bukanlah karya ilmiah formal, tapi perlu suatu persiapan yang memadai dan terprogram. Diperlukan penguasaan penulisan karya ilmiah yang baku.

Pada tahap persiapan, fokuskan penelitian pada permasalahan yang benar-benar dikuasai. Urgensinya, penguasaan permasalahan memungkinkan penyelesaian yang tuntas. Gunakanlah format observasi yang relevan dengan masalah yang diteliti. Selain peneliti, juga pengamat (supervisor) mesti menguasai teknik pengisian format observasi yang dimaksud. Kolaborasi peneliti dan pengamat menganalisis data berkontribusi pada hasil penelitian. Hasil Penelitian Tindakan Sekolah yang dilakukan penulis merupakan implementasinya. Keberhasilan Penelitian Tindakan Sekolah sekecil apa pun sangat bermanfaat bagi peningkatan kualitas pendidikan.

\section{DAFTAR PUSTAKA}

Drs. Alex S. Nitisemito, Manajemen Personalia, Edisi Revisi, Jakarta, Ghalia Indonesia, 1982

Eni Kurniawati, Pengembangan Bahan Ajar Bahasa dan Sastra Indonesia, 2009, Tesis, Surakarta: Program Pascasarjana Universitas Sebelas Maret.

Hamzah B. Uno, Mengelola Kecerdasan Dalam Pembelajaran, Jakarta: Bumi Aksara, 2009

Jurnal Dialektika Jurusan PGSD, Vol. 9 No. 2 September 2019, Safrudin, Penigkatan Kompetensi Guru Dalam Menyusun RPP 
Melalui Kegiatan Workshop Bagi Para Guru SDN SOKASARI 02 kecamatan Tegal Bumijawa Kabupaten Tegal, Semester II Tahum Pelajaran 2017/2018.

Republik Indonesia, Depdiknas, Kerangka Dasar Kurikulum 2004, Jakarta, 2004.

, Peraturan Pemerintah Republik Indonesia Nomor 19

Tahun 2005 Tentang Standar Nasional Pendidikan

, Peraturan Pemerintah Republik Indonesia Nomor 74

Tahun 2008 Tentang Guru

, Peraturan Pemerintah Republik Indonesia Nomor 19

Tahun 2005 tentang 8 Standar Nasional Pendidikan

, PermendikbudNomor 81A Tahun 2013 (Lampiran 4)

, Permendiknas No. 41 Tahun 2007

, Undang-Undang Republik Indonesia Nomor 14 Tahun 2005 Tentang Guru dan Dosen

, Undang-Undang Republik Indonesia Nomor 20 Tahun 2003 Tentang Sistem Pendidikan Nasional

, Undang-Undang Republik Nomor 2 tahun 1989 tentang Sistem Pendidikan Nasional

Suharsimi Arikunto, Prosedur Penelitian: Suatu Pendekatan Praktik, Jakarta: Rineka Cipta, 2011 